Dinullah, et al/Jurnal Ekonomi Syariah Teori dan Terapan Vol. 6 No. 10 Oktober 2019: 21 10-2125; PENDAYAGUNAAN MODAL SOSIAL PERSPEKTIF EKONOMI ISLAM PADA (STUDI KASUS KOPERASI SYARIAH DI PONDOK PESANTREN UMMUL QUROO SURABAYA)

\title{
PENDAYAGUNAAN MODAL SOSIAL PERSPEKTIF EKONOMI ISLAM PADA (STUDI KASUS KOPERASI SYARIAH DI PONDOK PESANTREN UMMUL QUROO SURABAYA)'
}

\author{
Muhammad Dinullah \\ Departemen Ekonomi Syariah-Fakultas Ekonomi dan Bisnis-Universitas Airlangga \\ Email: mdinullahgmail.com \\ Tika Widiastuti \\ Departemen Ekonomi Syariah-Fakultas Ekonomi dan Bisnis - Unversitas Airlangga \\ Email:widasus@yahoo.com
}

\begin{abstract}
:
Islamic economic empowerment is an activity of giving power, ability, or power to the helpless party with effort to help society to improve its ability in creating new entrepreneur in accordance with the laws of the Qur'an and Hadith. In the application of social capital-based that is trust, norm, and network is part of social life that can encourage the achievement of common goals. By means of Sharia cooperative and its network is useful to improve prosperity for society and jama'ah in the scope of hut. So it can empower santri and jama'ah to improve their economy. This research uses descriptive qualitative approach. The research strategy used is case study on Islamic Economic Empowerment based on social capital case study of sharia cooperative in Surabaya. Data collection used is by interview, observation and documentation. The validation technique uses source triangulation and engineering triangulation. Data analysis using the theory put forward by Miles and Huberman. The result of the research based on data analysis shows that the role of Kopontren Ummul Quroo is able to empower and give enough improvement of Islamic welfare where each informant has fulfilled at least the dharuriyat level requirement consisting of clothing needs, food requirement, health requirement, education requirement and requirement vehicle.
\end{abstract}

Keywords: Empowerment, Social Capital, and Sharia Cooperatives.

\section{PENDAHULUAN}

\section{Latar Belakang Masalah}

Seluruh alam seisinya dan segala kejadiannya, adalah dengan nama Allah. Allah lah yang mempunyai nama ArRahman dan Ar-Rahim, atas segala karunia dan nikmatnya maka seluruh penduduk umat manusia telah diberikan hidup dengan taraf ekonomi yang cukup, sedang, kaya dengan harta yang lebih bahkan juga miskin. Agama Islam yaitu agama yang mencakup segala pola hidup manusia baik digambarkan secara umum maupun secara lengkap (rinci). Allah menurunkan Agama
Islam kepada Rasulullah dibagi menjadi tiga, yaitu : akhlaq, aqidah dan syariah. Islam mengajarkan dan menata tingkah laku manusia, lebih lebih kepada sang Pencipta-Nya. Sesama mahluk hidup pun juga harus mempunyai prinsip yang bersosial. Syariah dalam kaidah ushul fiqih mempunyai ketentuan yang ada didalamnya terbagi menjadi dua, yaitu muamalah dan ibadah. Pengertian muamalah yaitu syariah yang mengatur hubungan antar sesama umat manusia (jual-beli). Sedangkan ibadah memiliki arti

\footnotetext{
${ }^{1}$ Jurnal ini merupakan bagian dari skripsi dari Muhammad Dinullah, NIM: 041311433094, yang diuji pada tanggal 18 Juli 2018.
} 
Dinullah, et al/Jurnal Ekonomi Syariah Teori dan Terapan Vol. 6 No. 10 Oktober 2019: 2110-2125; PENDAYAGUNAAN MODAL SOSIAL PERSPEKTIF EKONOMI ISLAM PADA (STUDI KASUS KOPERASI SYARIAH DI PONDOK PESANTREN UMMUL QUROO SURABAYA)

syariah yang mengatur hubungan antara manusia dengan Tuhannya.

Agama Islam menerangkan tentang aturan berekonomi, termasuk bagianbagian yang ada yaitu konsumsi, distribusi dan produksi. Pernyataan ini menunjukkan Islam dengan Al-Quran yang telah menata sistem ekonomi yang efektif, tak lepas dari agama Islam yang mampu dan membuktikan perkembangan sistem ekonomi yang ada di kalangan ummat. Didalam firman Allah terdapat surat Al-Hasyr ayat 7 yaitu anjuran untuk pemerataan harta di semua kalangan umat manusia :

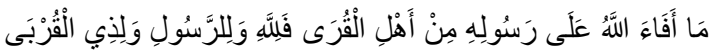

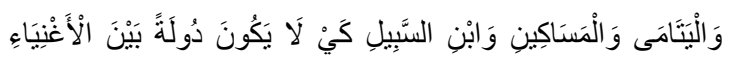

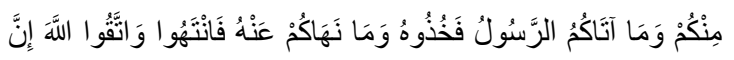
اللَّة شَدَيدُ الْعِقَاب. Mā afā'a'llāhu 'alā rasūlihī min ahli'l-qurā falillāhi wa lirrasūli wa liżi'--qurbā walyatāmā walmasākīni wabni's-sabīi kai lā yakūna dūlatan baina'l-agniyā'i minkum wa mā ātākumu'r-rasūlu fakhużūhu wa mā nahākum 'anhu fantahū wattaqu'llāha inna'llāha syadīdu'l-'iqāb.

Artinya: "Harta rampasan fai' yang diberikan Allah kepada Rasul-Nya (yang berasal) dari penduduk beberapa negeri, adalah untuk Allah, Rasul, kerabat (Rasul), anak-anak yatim, orang-orang miskin dan untuk orang-orang yang dalam perjalanan, agar harta itu jangan beredar diantara orang-orang kaya saja di antara kamu. Apa yang diberikan Rasul kepadamu maka terimalah. Dan apa yang dilarangnya bagimu maka tinggalkanlah. Dan bertakwalah kepada Allah. Sungguh, Allah sangat keras hukuman-Nya" (Kementerian Agama Rl, 2014: 546).

Ayat ini memiliki kaidah besar dalam sistem ekonomi dan sosial dalam masyarakat muslim. Kepemilikan pribadi diakui dalam Islam, namun dibatasi dengan kaidah agar "jangan beredar diantara orang-orang kaya saja". Sehingga menciptakan kehidupan yang seimbang (Quthb, 2004: 211-212).

Dapat dipahami diatas, bahwa menurut Islam ekonomi yang bersumber dari Al-Qur'an dan Hadits itu memberikan peranan penting dalam memberikan dasardasar pada sistem perekonomian. Didalam agama islam pun kita juga diajarkan adanya rasa tolong menolong sesama mahluk Allah juga sikap kebersamaan dan saling membutuhkan ini dapat dikatakan sebagai salah satu bentuk modal sosial. Fukuyama (1999:22) mengartikan modal sosial adalah serangkaian norma atau nilai informal yang dimiliki bersama diantara para anggota suatu kelompok yang memungkinkan terjalinnya kerja sama antara mereka. Berbagai macam jawaban diatas dapat ditarik kesimpulan modal sosial adalah serangkaian nilai atau norma yang memungkinkan masyarakat untuk saling bekerjasama dalam mencapai tujuan bersama.

Pondok pesantren umumnya memiliki fungsi tidak hanya sebagai untuk tempat pendidikan semata, namun juga tempat untuk kegiatan dakwah dan wadah yang menyeluruh untuk belajar ilmu agama lebih dalam. Ponpes adalah singkatan dari 
Dinullah, et al/Jurnal Ekonomi Syariah Teori dan Terapan Vol. 6 No. 10 Oktober 2019: 2110-2125; PENDAYAGUNAAN MODAL SOSIAL PERSPEKTIF EKONOMI ISLAM PADA (STUDI KASUS KOPERASI SYARIAH DI PONDOK PESANTREN UMMUL QUROO SURABAYA)

pondok pesantren yang mempunyai arti sebuah lembaga keagamaan yang sangat tradisional dengan para santri yang tinggal bersama di kamar dan belajar dibawah naungan ustadz atau kyai. Ponpes ini tidak hanya mencetak kyai, da'l, kader atau ahli dalam kitab kuning, tetapi menghasilkan karya yang luar biasa, dengan bekal ilmu yang didapatnya dalam pondok, santri dibimbing dan dicetak agar memiliki sumber daya yang unggul, lebih lebih pandai ilmu agama dan pandai ilmu ekonomi islam sehingga membangun ekonomi ummat khususnya para jama'ah serta memberdayakan potensi santri dan masyarakat sekeliling pondok pesantren Ummul Quroo Surabaya. Lembaga Kajian Islam Pondok Pesantren Ummul Quroo yang beralamat di Jl.Semolowaru No.110 Surabaya, adalah lembaga pendidikan Islam yang salah satu misinya mewujudkan persatuan dan kesatuan ummat, dalam bidang pendidikan juga mengadakan berbagai macam kegiatan dalam rangka meningkatkan kualitas pendidikan Islam dan juga dalam pemberdayaan ekonomi ummat melalui koperasi syariah.

Di pesantren ini, santri/ jama'ah yang menuntut ilmu disana berasal dari berbagai ormas Islam yang ada. Baik NU, Muhammadiyah, Salafi dan Tarbiyah. Pondok pesantren Ummul Quroo sangat memiliki harapan yang besar untuk membangun dan memberdayakan ekonomi ummat. Sehingga perekonomian jamaah meningkat dan bisa memberdayakan ekonomi masyarakat sekeliling Pondok Pesantren Ummul Quroo akan menjadi lebih baik dan sejahtera.

\section{Rumusan masalah}

Bagaimana Pemberdayaan Ekonomi Islam berbasis modal sosial studi kasus koperasi syariah di pondok pesantren Ummul Quroo Surabaya?

\section{Tujuan Penelitian}

Berdasarkan rumusan masalah diatas maka tujuan penelitian ini adalah untuk mengetahui dan memahami peran pondok pesantren Ummul Quroo surabaya dalam pengembangan modal sosial dan meningkatkan kesejahteraan jamaah dan masyarakat sekitar.

\section{LANDASAN TEORI}

\section{Pemberdayaan Ekonomi Islam}

Kalimat pemberdayaan diambil dari kata dasar "daya" yang artinya kekuasaan atau kemampuan, yaitu memberi kekuasaan/keberdayaan pada pihak lain. Kekuasaan disini tidak identik dengan politik melainkan kekuasaan dalam arti yang luas. Adapun definisi pemberdayaan secara istilah banyak diungkapkan oleh para ahli dengan perspektif yang general (Prijono dan Pranarka, 1996:3).

Menurut Muslim (2014:16) yakni pemberdayaan ekonomi masyarakat adalah upaya membantu masyarakat untuk meningkatkan kemampuannya dalam menciptakan wirausaha baru, peningkatan akses pada asset produksi, memperkuat posisi transaksi dan kemitraan usaha dengan cara berpartisipasi aktif dalam proses pengambilan keputusan dan dalam menentukan pilihan masa depannya. 
Dinullah, et al/Jurnal Ekonomi Syariah Teori dan Terapan Vol. 6 No. 10 Oktober 2019: 2110-2125; PENDAYAGUNAAN MODAL SOSIAL PERSPEKTIF EKONOMI ISLAM PADA (STUDI KASUS KOPERASI SYARIAH DI PONDOK PESANTREN UMMUL QUROO SURABAYA)

Sehingga dapat disimpulkan bahwa pengertian inti dari pemberdayaan ekonomi adalah suatu kegiatan pemberian daya, kemampuan, atau kekuasaan kepada pihak yang tak berdaya atau powerless agar mampu dalam aspek perekonomiannya.

Adapun Agama Islam juga memiliki hubungan yang erat dengan ekonomi. Banyak penelitian yang telah membahas hal tersebut, diantara penelitian yang terbaru adalah Korelasi Antara Islam dan Ekonomi (Akmal dan Abidin, 2015), Masalah ekonomi ini seakan-akan tidak ada hubungannya dengan masalah keagamaan, tetapi keduanya memiliki orientasi yang berbeda yakni dunia dan akhirat. Faktanya, kedua hal tersebut ibarat mata vang yang tidak dapat dipisahkan (Fitrianto, 2005:1). Disisi lain juga sebenarnya masalah perekonomian memiliki bobot yang besar dalam agama, meskipun hal itu dikategorikan dalam urusan keduniaan (muamalah) (Nadzir, 2015:44). Terdapat dalil dalam firman Allah QS. AI Qashash (28) ayat 77:

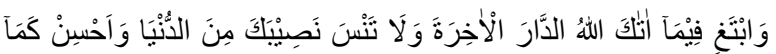

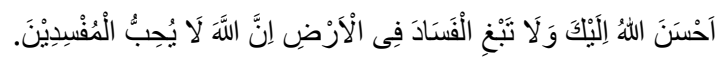
Wa'btagī fímā ātāka'llāhu'd-dāra'l-ākhirata wa lā tansa nașibaka mina'd-dunyā wa ahsin kamā ahsana'llāhu ilaika wa lā tabgi'lfasāda fi'l-arọi inna'llāha lā yuhibbu'lmufsidin. Artinya: "Dan carilah (pahala) negeri akhirat dengan apa yang telah dianugerahkan Allah kepadamu, tetapi janganlah kamu lupakan bagianmu di dunia dan berbuat baiklah (kepada orang lain) sebagaimana Allah telah berbuat baik kepadamu, dan janganlah kamu berbuat kerusakan di bumi. Sungguh Allah tidak menyukai orang yang berbuat kerusakan" (Kementerian Agama Rl, 2014: 394).

Ayat tersebut menjelaskan tentang keseimbangan antara kehidupan dunia dan akhirat, yang mengajarkan manusia untuk menggantungkan hatinya dengan akhirat dan tidak melarang, bahkan mendorong, manusia untuk mencari harta di dunia. Sehingga manusia tidak menjadi sosok yang membenci dunia, menyia-nyiakan dunia, dan melemahkan kehidupan dunia. Sebab pada hakikatnya, kenikmatan dunia yang telah Allah ciptakan ini ditujukan untuk manusia agar dikelola dan dimanfaatkan (Quthb, 2004:72). Islam mengajarkan agar tidak mengabaikan urusan dunia sebab manusia hidup diatasnya, dan tidak melupakan urusan akhirat sebab manusia akan menuju kesana. Maka dengan berekonomi/ber-muamalah dan beribadah, manusia dapat menjalankan kehidupan dunia dan akhiratnya dengan seimbang. Kudhori (2013:20) mengartikan pemberdayaan dengan kata القوّة alquwwah yang bermakna daya atau kekuatan. Menurut Sanrego dan Taufik (2016:75-76) pemberdayaan dalam bahasa Arab dapat diistilahkan dengan kata تمكين(tamkinn) yang berupa masdar dari kata kerja atau fi'il (makana). Kata tamkinn disebutkan 18 kali didalam Al-Quran dengan memiliki banyak makna, yang kemudian disimpulkan dengan makna yang menunjuk pada kemampuan atas sesuatu 
Dinullah, et al/Jurnal Ekonomi Syariah Teori dan Terapan Vol. 6 No. 10 Oktober 2019: 2110-2125; PENDAYAGUNAAN MODAL SOSIAL PERSPEKTIF EKONOMI ISLAM PADA (STUDI KASUS KOPERASI SYARIAH DI PONDOK PESANTREN UMMUL QUROO SURABAYA)

yang memiliki kekuatan, kekuasaan, berpengaruh dan memiliki kedudukan atau tempat baik hissi (materi) atau ma'nawi (nonmateri). Lebih lanjut, Muhammad Raihan dalam Sanrego dan Taufik (2016:77) mendefinisikan kata tamkin secara eksplisit dengan makna pemberdayaan:

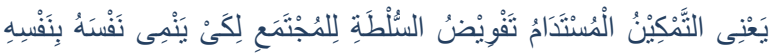

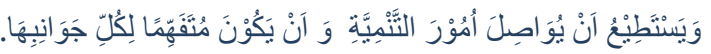
Ya'ni't- + amkīnu'l-mustadāmu

tafwiḍu's-sulțati lilmujtamai likai yanmĩ nafsahu binafsihi wa yastați'u an yuwāșila umūra't-tanmiyyati wa an yakūna mutafahhiman likulli jawānibihā.

Artinya: "Pemberdayaan

yang berkelanjutan (at-tamkīn al-mustadām) maksudnya adalah memberikan kekuasaan penuh kepada masyarakat agar dirinya berkembang dan bisa mencapai pengembangan tersebut dan ia memahaminya dari segala sisi". Sehingga dari pendefinisian Raihan dalam disertasinya tersebut, dapat disimpulkan bahwa konsep pemberdayaan lebih sesuai maknanya dengan kata tamkin, yang kemudian melalui kata tersebut dapat diambil keterangannya dari Al Quran atau dalil yang lain. Selanjutnya, dari penafsiran kata tamkin dalam Al Quran tersebut, Sanrego dan Taufik (2016:85-86) menyimpulkan bahwa tamkin dapat dibedakan menjadi dua bentuk, yaitu صيغة التمكين في الثيءbentuk tamkin pada suatu hal) dan صبغة تمكين الثيء (bentuk tamkin terhadap suatu hal). Bentuk yang pertama merupakan untuk tamkin di atas bumi, yang kedua mencakup tamkin atas agama, harta, kekuasaan dan kekuatan. Jadi kata tamkīn dapat dikelompokkan menjadi pemberdayaan materi dan nonmateri.

\section{Modal Sosial}

Menurut Bourdieu dan Wacquant (1992:119) dalam Field (2003:23) modal sosial adalah "jumlah sumber daya, aktual atau maya, yang berkumpul pada seorang individu atau kelompok karena memiliki jaringan tahan lama berupa hubungan timbal balik perkenalan dan pengakuan yang sedikit banyak terinstitusionalisasikan". Coleman dalam Fukuyama (1995:12) menyebutkan bahwa social capital adalah "masyarakat mampu untuk bekerja sama dengan konsep sosial demi mencapai tujuan bersama di dalam berbagai organisasi maupun kelompok". Dengan berbagai pendapat diatas, modal sosial dapat disimpulkan yaitu sumber daya yang tersedia dalam kehidupan sosial masyarakat berupa norma-norma, kepercayaan, dan jaringan yang mana dapat mendorong terciptanya kerja sama untuk mencapai tujuan bersama.

Istilah modal sosial mulai dikenal pada abad ke-19, maka Islam telah lebih dahulu memberikan konsep-konsep modal sosial ketika Al-Qur'an diturunkan pada Nabi Muhammad SAW. Dengan Al-Qur'an, Allah memberikan pedoman pada manusia dalam menjalani perannya sebagai hamba Allah dan khalifah di muka bumi. Adapun Hadits atau Sunnah Rasulullah SAW menjadi pedoman kedua bagi manusia dalam menjalankan berbagai syariat Islam. Jadi sudah sangat jelas bahwa Islam memiliki 
Dinullah, et al/Jurnal Ekonomi Syariah Teori dan Terapan Vol. 6 No. 10 Oktober 2019: 2110-2125; PENDAYAGUNAAN MODAL SOSIAL PERSPEKTIF EKONOMI ISLAM PADA (STUDI KASUS KOPERASI SYARIAH DI PONDOK PESANTREN UMMUL QUROO SURABAYA)

landasan kuat dalam mengembangkan modal sosial. Menurut Minarti (2003) dalam Wahyuningsih (2016:47) Islam mempunyai komitmen terhadap kontrak sosial dan norma yang telah disepakati bersama; dan bangunan masyarakat Muslim dasarnya adalah tadhomun (memiliki solidaritas), takaful (saling menanggung) dan ta'awun (tolong-menolong) Sikap tersebut dalam Islam sering dinamakan dengan konsep ukhuwah islamiyah (persaudaraan antar umat Islam).

Bila kita cermati, dalam Al-Qur'an terdapat ayat-ayat yang yang menganjurkan umatnya untuk senantiasa membangun hubungan yang baik antar sesama manusia. Diantaranya mengandung perintah untuk saling menolong orang lain, bermusyawarah, bekerjasama, amanah, berkata jujur, menghormati orangtua, dan lain sebagainya. Ikatan ukhuwah Islamiyah adalah pondasi kuat dari bangunan modal sosial, serta dapat menjadi perekat bagi masyarakat sehingga mereka dapat saling bekerja sama, bergotong royong, dan bersatu padu dalam mencapai tujuan bersama termasuk salah satunya adalah pembangunan ekonomi (Sanrego dan Taufik, 2016:138). Pada masa awal turunnya Islam, Rasulullah telah mencontohkan bagaimana beliau membangun Madinah dan masyarakatnya menjadi masyarakat madani, atau dalam istilah saat ini dikenal dengan civil society. Madinah kala itu menjadi pusat peradaban umat Islam. Baik umat Islam maupun non Islam yang tinggal di Madinah dapat berjalan selaras dan harmoni serta menjunjung tinggi adab dan moral-moral kebaikan. Masyarakat Madinah pun memiliki tatanan sosial yang baik serta saling menjaga keseimbangan hak dan kewajiban individu dan masyarakat.

Bagi umat Islam, agama Islam merupakan ajaran yang lurus, bersih, dan damai. Islam senantiasa mendorong manusia untuk bersikap jujur, saling tolong menolong, mempercayai satu sama lain, saling mengingatkan dalam kebaikan, serta membangun jaringan yang baik dengan sesama manusia. Islam juga menganjurkan umatnya untuk bekerjasama dalam menyelesaikan berbagai problematika bersama sehingga Islam dapat menjadi agama rahmatan lil alamin (Hasbullah (2006:95) menyatakan bahwa "berusaha, bekerja, silaturahmi, berinteraksi dan bekerjasama merupakan api modal sosial Islam yang menyala". Islam adalah agama yang mendorong pembangunan manusia, sehingga ajaran-ajaran yang terkandung di dalamnya tidak lain adalah untuk membentuk umat terbaik atau khoirul ummah. Apabila nilai-nilai Islam berkembang baik dalam kehidupan masyarakat, maka tidak akan ada desadesa yang buminya makmur tetapi terdapat kemiskinan yang tinggi, tidak akan ada anak yatim yang terdzolimi, tidak akan ada korupsi, dan tidak akan ada orangorang yang saling mendzolimi (Hasbullah, 2006:95). Dengan kata lain, modal sosial dalam Islam adalah kumpulan nilai, norma, dan jaringan yang sesuai dengan syari'at 
Dinullah, et al/Jurnal Ekonomi Syariah Teori dan Terapan Vol. 6 No. 10 Oktober 2019: 2110-2125; PENDAYAGUNAAN MODAL SOSIAL PERSPEKTIF EKONOMI ISLAM PADA (STUDI KASUS KOPERASI SYARIAH DI PONDOK PESANTREN UMMUL QUROO SURABAYA)

Islam, yang tumbuh dari pondasi ukhuwah Islamiyah yang dapat mendorong masyarakat untuk menghasilkan kesuksesan di dunia maupun di akhirat serta membentuk ummat yang baik (khoirul ummah).

\section{Koperasi di Pondok Pesantren}

Mengupas definisi Kopontren secara bahasa maupun istilah mungkin tidak akan menemukannya, akan tetapi penulis mencoba menyimpulkan melalui penggabungan dua pengertian yang ada, yaitu dari kata Koperasi dan Pondok Pesantren.Koperasi mempunyai arti "kerja sama". Istilah koperasi dari bahasa Latin "coopere" yang dalam bahasa Inggris disebut cooperation. Co berarti bersama dan operation berarti bekerja, jadi cooperation dapat diartikan "bekerja sama". Dapat diartikan koperasi yaitu kerjasama yang dilakukan oleh sekelompok orang-orang yang mempunyai tujuan dan kepentingan secara bersama. Dalam bahasa terminologi koperasi sendiri mempunyai arti "kerjasama" atau paling tidak mengandung arti kerja sama. Sedangkan pengertian koperasi secara etimologi menurut (Arifinal Chaniago) la mengemukakan koperasi sebagai perkumpulan atau sekelompok yang beranggotakan orang-orang atau badan hukum, dengan kerjasama secara kekeluargaan dalam menjalankan usaha untuk mempertinggi kesejahteraan jasmaniah para anggotanya serta memberikan kebebasan kepada anggotaanggotanya untuk masuk dan keluar.
Dooren mengemukakan pengertian koperasi, di mana koperasi tidak hanya semata-mata berupa kumpulan orangorang saja, akan tetapi koperasi juga dapat terdiri dari badan- badan hukum (coporate). Muhammad Hatta mendefinisikan koperasi adalah usaha bersama untuk memperbaiki nasib penghidupan ekonomi berdasarkan prinsip tolongmenolong.Semangat tolongmenolon g yang ada didorong oleh keinginan memberi rasa peduli kepada kawan dan tidak pilih kasih terhadap sesama.

Pengertian Koperasi menurut Undang-Undang No. 25/1992 adalah badan usaha yang beranggotakan perseorangan atau badan hukum, yang berlandaskan prinsip-prinsip koperasi sekaligus sebagai gerakan ekonomi rakyat yang berdasarkan atas rasa kekeluargaan dan saling menolong. Definisi-definisi koperasi di atas dapat diartikan yaitu koperasi yang dituturkan oleh para tokoh perkoperasian satu dengan yang lainnya memiliki suatu kesamaan. Dilihat dari tujuan dibentuknya koperasi maka akan ditemukan suatu pengertian, yaitu adanya unsur kekeluargaan antara sesama anggota koperasi yang memiliki tujuan untuk memperbaiki atau meningkatkan nasib penghidupan perekonomian dan mempertinggi kesejahteraan berdasarkan tolong- menolong di antara anggotanya.

\section{METODE PENELITIAN}

Pendekatan Penelitian

Pendekatan kualitatif adalah pendekatan dengan menggunakan data 
Dinullah, et al/Jurnal Ekonomi Syariah Teori dan Terapan Vol. 6 No. 10 Oktober 2019: 2110-2125; PENDAYAGUNAAN MODAL SOSIAL PERSPEKTIF EKONOMI ISLAM PADA (STUDI KASUS KOPERASI SYARIAH DI PONDOK PESANTREN UMMUL QUROO SURABAYA)

yang berupa kalimat tertulis atau lisan, peristiwa-peristiwa, pengetahuan atau proyek studi yang bersifat deskriptif. (Yin 2002 dalam Bungin 2007)

Strategi penelitian ini adalah studi kasus. Studi kasus adalah suatu inkuiri empiris yang menyelidiki fenomena dalam konteks kehidupan nyata, bilamana, batas-batas antara fenomena dan konteks tak tampak dengan tegas dan di mana, multi sumber dapat dimanfaatkan (Yin, 1996, dalam Bungin 2003:20). Selain melakukan observasi untuk memperoleh data empiris, peneliti juga menggunakan metode wawancara untuk memperoleh data dari responden yang bersangkutan.

\section{Ruang Lingkup Penelitian}

Ruang lingkup penelitian berkaitan dengan rumusan masalah yang digunakan pada penelitian ini. Rumusan masalah pada penelitian ini adalah "Bagaimana pemberdayaan ekonomi islam berbasis modal sosial studi kasus koperasi syariah di Pondok Pesantren Ummul Quroo Surabaya." Rumusan masalah tersebut akan menjadi acuan peneliti dalam menentukan ruang lingkup penelitian ini, yakni seberapa besar peran Pondok Pesantren Ummul Quroo Surabaya dalam membangun modal sosial masyarakat setempat. Ruang lingkup penelitian terbatas dan fokus pada program dan manajemen koperasi syariah di Pondok Pesantren Ummul Quroo Surabaya, serta masyarakat yang memiliki hubungan langsung dengan koperasi syariah tersebut, serta mencari jawaban bagaimana modal sosial berperan dalam meningkatkan ekonomi masyarakat dan kesejahteraan masyarakat.

\section{Teknik Penentuan Informan}

Informan adalah orang yang diprediksi mengetahui, menguasai dan memahami data, informasi, ataupun fakta dari suatu objek penelitian. Dalam penelitian ini, penentuan informan menggunakan purposive sampling, dimana sampel ditentukan dengan pertimbangan tertentu. Adapun kriteria informan adalah sebagai berikut :

1. Pengelola koperasi syariah atau jama'ah Pondok Pesantren

2. Tinggal di lingkungan sekitar Pondok Pesantren Ummul Quroo

3. Bersedia diwawancara dan menjadi informan dalam penelitian ini

Yang menjadi informan kunci dalam penelitian ini adalah para Pimpinan dan Pengasuh Pondok Pesantren, dimana Pengasuh Pondok Pesantren ini dianggap adalah orang yang mengetahui seluk beluk dan sejarah koperasi syariah di Pondok Pesantren Ummul Quroo dan turut mengelola Pondok Pesantren hingga saat ini.

\section{Jenis dan Sumber Data}

Jenis dan sumber data yang digunakan pada penelitian ini adalah data primer dan data sekunder. Data primer merupakan data utama yang berasal dari hasil observasi langsung dan wawancara mendalam di lapangan. Data yang ada dikumpulkan melalui proses wawancara dimana peneliti dapat bertatap muka langsung dengan informan dan menggali 
Dinullah, et al/Jurnal Ekonomi Syariah Teori dan Terapan Vol. 6 No. 10 Oktober 2019: 2110-2125; PENDAYAGUNAAN MODAL SOSIAL PERSPEKTIF EKONOMI ISLAM PADA (STUDI KASUS KOPERASI SYARIAH DI PONDOK PESANTREN UMMUL QUROO SURABAYA)

secara langsung dan mendalam sehingga dapat dipertanggung jawabkan validitas datanya. Data primer sebagai data utama pada penelitian ini, didapat dengan wawancara langsung dengan 7 informan, yakni 1 orang narasumber (pengasuh) yang berasal dari Pondok Pesantren, 1 orang narasumber (Pimpinan) Koperasi Pondok. 3 orang pengurus Koperasi Pondok Pesantren, 2 Jama'ah Pondok Pesantren Ummul Quroo Surabaya. Sedangkan data sekunder pada penelitian berupa dokumen, baik cetak maupun elektronik.

\section{Teknik Pengumpulan Data}

teknik pengumpulan data merupakan langkah yang paling strategis dalam penelitian, karena tujuan utama dari penelitian adalah mendapatkan data.

Adapun penjelasan mengenai teknik pengumpulan data yang dilakukan dalam penelitian ini adalah:

1. Wawancara Mendalam (in-depth interview)

Bungin (2007) mendefinisikan wawancara mendalam adalah proses memperoleh keterangan untuk tujuan penelitian dengan cara tanya jawab sambil bertatap muka antara pewawancara dengan informan atau orang yang diwawancarai, dengan atau tanpa menggunakan pedoman wawancara, dimana pewawancara dan informan terlibat dalam kehidupan sosial yang relatif lama. Pada penelitian ini proses wawancara dilakukan kepada pengelola dan jama'ah Pondok Pesantren, yang mana jenis pertanyaan yang akan dibahas adalah mengenai peran koperasi syariah Pondok Pesantren Ummul Quroo dalam upaya meningkatkan ekonomi dan pembangunan modal sosial.

2. Observasi Partisipasi

Observasi partisipasi adalah pengumpulan data melalui observasi terhadap objek pengamatan dengan langsung hidup bersama, merasakan serta berada dalam aktivitas kehidupan objek pengamatan. Pada penelitian ini peneliti ikut berinteraksi dengan narasumber dalam keseharian serta menjadi jama'ah Pondok Pesantren dan mengikuti beberapa kegiatan Pondok Pesantren sehingga timbul keakraban.

3. Studi Dokumentasi

Peneliti menggunakan dokumen pendukung sebagai pelengkap untuk mendapatkan hasil pengamatan yang maksimal. Dokumen pendukung ini berupa data dan laporan yang diperoleh dari Pondok Pesantren Ummul Quroo Surabaya. Peneliti juga mengambil gambar sebagai bukti dokumentasi pengamatan yang dilakukan.

\section{Teknik Keabsahan Data}

Dalam penelitian ini digunakan teknik keabsahan data yang dikemukakan oleh Sugiyono. Menurut Sugiyono dalam bachri (2010: 330) terdapat tiga teknik triangulasi sebagai teknik dalam menilai keabsahan data, yaitu:

1) Triangulasi Sumber

Triangulasi sumber merupakan teknik pengujian dengan cara mengecek 
Dinullah, et al/Jurnal Ekonomi Syariah Teori dan Terapan Vol. 6 No. 10 Oktober 2019: 2110-2125; PENDAYAGUNAAN MODAL SOSIAL PERSPEKTIF EKONOMI ISLAM PADA (STUDI KASUS KOPERASI SYARIAH DI PONDOK PESANTREN UMMUL QUROO SURABAYA)

kredibilitas atau keakuratan data yang diperoleh dari beberapa sumber penelitian.

2) Triangulasi Teknik

Triangulasi teknik merupakan teknik pengujian data dengan menguji kredibilitas data yang dilakukan dengan cara mengecek data kepada sumber yang sama dengan teknik lain.

3) Triangulasi Waktu

Triangulasi waktu ini merupakan teknik yang dapat mempengaruhi kredibilitas data yang dihasilkan yaitu waktu. Data yang dikumpulkan yaitu dengan cara wawancara di pagi hari pada saat narasumber masih segar, akan menghasilkan data yang lebih valid dan kredibel.

\section{Teknik Analisis Data}

Setelah melakukan pengumpulan data dengan menggunakan pendekatan tersebut diatas, kemudian dilakukan teknik analisis data. Teknik analisis data ini dimaksudkan agar data yang diperoleh dari lapangan dapat dengan mudah dibaca dan dipahami sebagai upaya untuk menemukan jawaban atas permasalahan penelitian.

Menurut Wibowo (2014:10) yang dilakukan dalam penelitian ini adalah sebagai berikut:

1. Membuat proposisi awal

Pada saat awal penelitian, proposisi berguna untuk membantu memfokuskan pada data tertentu. Proposisi juga berguna membentuk rencana pengumpulan data. Proposisi awal dalam penelitian ini adalah apabila keberadaan koperasi syariah Pondok
Pesantren Ummul Quroo mampu berperan dalam mengembangkan modal sosial masyarakat sekitar dengan baik maka dapat mensejahterakan dan menciptakan ikatan ukhuwah islamiyah yang kuat.

2. Membandingkan temuan awal dengan data wawancara

Pada tahap ini temuan awal yang telah diperoleh dibandingkan dengan data yang didapat ketika melakukan wawancara langsung di lapangan, sehingga dapat diketahui perbedaan dari data atau temuan yang didapat.

3. Memperbaiki proposisi

Setelah membandingkan temuan awal dengan data yang di peroleh di lapangan melalui wawancara, maka proposisi diperbaiki agar dapat memenuhi rumusan masalah penelitian.

4. Membandingkan proposisi dengan fakta Untuk menjodohkan pola, maka dilakukan perbandingan untuk mencari kesesuaian antara proposisi penelitian dengan fakta yang ada di lokasi penelitian.

5. Mengulangi proses analisis data

Proses ini dilakukan untuk mengetahui apakah data yang didapat sudah memadai dan sudah cukup untuk menjawab permasalahan yang ada.

\section{HASIL ANALISIS DAN PEMBAHASAN}

\section{Pembahasan}

Modal sosial menjadi unsur yang berpengaruh dalam proses pembangunan ekonomi. Modal sosial sama seperti pengertian modal lainnya, yaitu sumber 
Dinullah, et al/Jurnal Ekonomi Syariah Teori dan Terapan Vol. 6 No. 10 Oktober 2019: 2110-2125; PENDAYAGUNAAN MODAL SOSIAL PERSPEKTIF EKONOMI ISLAM PADA (STUDI KASUS KOPERASI SYARIAH DI PONDOK PESANTREN UMMUL QUROO SURABAYA)

daya yang digunakan untuk meningkatkan produktivitas. Lain dengan itu, modal sosial juga berguna untuk meningkatkan efisisensi dan efektivitas produksi, tentunya modal sosial lambat laun akan habis, apabila tidak dijaga dan dikembangkan, untuk itu upayaupaya dalam mengembangkan modal sosial menjadi penting. Modal sosial dibagi menjadi tiga yaitu kepercayaan, norma, dan jaringan. Salah satu unsur yang akan di analisis dalam penelitian ini adalah jaringan, menurut Lawang (2004: 63) "jaringan yang dibahas dalam kapital sosial, menunjuk pada semua hubungan dengan orang atau kelompok lain yang memungkinkan pengatasan masalah dapat berjalan secara efisien dan efektif." Lebih lanjut Lawang mengemukaan tiga bentuk jaringan, yaitu: (1) Jaringan antar individu; (2) Jaringan antar individu dan institusi dan (3) Jaringan antar institusi.

Pondok Pesantren sebagai institusi keagamaan yang tersebar di berbagai daerah di Indonesia memiliki peluang besar dalam mengembangkan modal sosial ini. Pondok dengan berbagai aktivitas, kegiatan, serta manajemennya selalu melibatkan antara pengurus Pondok dengan jamaah dan para santri. Aktivitas ini tentunya akan menimbulkan interaksiinteraksi sosial yang mana akan menjadi bibit-bibit Ukhuwah Islamiyah. Jalinan ukhuwah yang terjadi di Pondok ini kemudian akan membantu mengembangkan modal sosial yang ada diantara jama'ah. Pada penelitian ini, Pondok Pesantren Ummul Quroo menjadi objek yang diteliti mengenai pemberdayaan berbasis modal sosial melalui jaringan-jaringan yang terbentuk di Pondok.

\section{Proses Pembentukan Jaringan Antar Individu}

Proses terbentuknya jaringan tentulah berawal dari komunikasi dan interaksi antar individu. Komunikasi singkat akan membawa pada interaksi yang lebih lanjut jika diiringi adanya keperluan maupun kebutuhan. Interaksi yang terjadi menunjukkan bahwa jaringan sudah mulai terbentuk. Lawang (2004:63) membagi bentuk jaringan berdasarkan jumlah orang sebagai berikut:

1. Jaringan antara dua orang tunggal

2. Jaringan antara dua orang ganda

3. Jaringan antara dua orang ganda berlapis

4. Jaringan antara tiga, empat, atau lima orang

Pembentukan jaringan antar individu sangat mungkin terjadi di dalam Pondok. Pondok sebagai institusi keagamaan memiliki fungsi utama sebagai tempat pembelajaran. Pembelajaran wajib dalam agama Islam salah satunya adalah menuntut ilmu. Islam sangat menganjurkan untuk menuntut ilmu di tempat tempat pengajian. Pondok Pesantren adalah sebagai sarana utama untuk menuntut ilmu dengan baik dan secara urut. Di dalam sebuah Pondok yang berada di suatu wilayah berkumpul individu-individu dengan keperluan yang sama yaitu menuntut ilmu. Tidak jarang pula ditemui di Pondok yang berisikan santri atau jama'ah yang tidak 
Dinullah, et al/Jurnal Ekonomi Syariah Teori dan Terapan Vol. 6 No. 10 Oktober 2019: 2110-2125; PENDAYAGUNAAN MODAL SOSIAL PERSPEKTIF EKONOMI ISLAM PADA (STUDI KASUS KOPERASI SYARIAH DI PONDOK PESANTREN UMMUL QUROO SURABAYA)

berasal dari wilayah sekitar, Sehingga dari berbagai macam wilayah yang berkumpul menjadi satu dengan tujuan yang sama.

Berdasarkan hasil pengamatan yang dilakukan oleh peneliti, Pondok Pesantren Ummul Quroo hampir dipenuhi oleh jamaah setiap seminggu sekali yaitu hari ahad. Banyak dari para jama'ah yang berasal dari luar kota dari Sidoarjo, Gresik dan Sekitarnya. Jama'ah ngaji di Pondok Pesantren Ummul Quroo pun juga sangat kompak dan bersatu, Apabila ada berita teman teman jama'ah sakit seluruh jama'ah yang hampir 400 orang itu mendoakan bersama dengan dipimpin Ustadznya, begitu juga apabila mendapat kabar duka maka para jamaah tersebut beramai-ramai mengunjungi rumah duka untuk menyolatkan bersama bagi yang tidak berhalangan.

Pondok Pesantren Ummul Quroo memiliki beberapa kegiatan pengajian yang mana pengajian tersebut didasarkan pada jadwal yang ada. Terdapat beberapa kelompok pengajian yaitu KAJIAN AHAD PAGI (umum semua kalangan), PESAD (Pesantren Sabtu dan Ahad) untuk anakanak, remaja hingga dewasa. Pengajian IBU LANSIA (khusus untuk ibu-ibu yang sudah lanjut usia), Pengajian JILING (ngaji keliling) untuk pemuda dan bapak-bapak. Adanya beberapa jadwal dalam kegiatan tersebut memudahkan jama'ah untuk menjalin komunikasi dan interaksi karena adanya beberapa kesamaan. Tidak hanya itu, Pondok Pesantren Ummul Quroo juga membentuk komunitas-komunitas berdasarkan kesenangan yaitu hobi, seperti Ummul Quroo speed Touring (jamaah Pondok yang suka adventure touring ), Sunnah Sport (panahan, renang dan tapak suci), REMUQ (Remaja Ummul Quroo).

Selain sebagai daya tarik agar jama'ah aktif berkegiatan di pondok, komunitaskomunitas ini semakin menambah peluang bagi jama'ah untuk memperluas interaksi dan jaringan. Menurut Lawang (2004: 252) pengembangan modal sosial akan lebih mudah terjadi bila sarana yang digunakan berupa komunitas sosial yang memiliki tradisi kebersamaan yang cukup lama. Sayangnya dalam komunitas hobi yang dibentuk oleh Pondok Pesantren Ummul Quroo saat ini masih terbatas pada jamaah laki-laki saja, belum ada komunitas hobi yang dikhususkan atau dapat diikuti oleh jamaah perempuan terutama remaja.

Tersedianya berbagai komunitas tersebut menunjukkan adanya komunikasi, interaksi, serta kerjasama yang pada akhirnya akan membentuk suatu jaringan. Adanya jaringan antar individu ini membuka peluang untuk saling mengetahui bagaimana kondisi masing-masing personal, yang mana pada tingkatan tertentu akan menumbuhkan rasa kepedulian antar sesama. Tentu saja dalam hal ini dibutuhkan partisipasi aktif antar individu. Individu yang berpartisipasi aktif dalam suatu jaringan akan memudahkan dalam mengembangkan modal sosial pada masyarakat.

Proses Pembentukan Jaringan Antar Individu dan Institusi 
Dinullah, et al/Jurnal Ekonomi Syariah Teori dan Terapan Vol. 6 No. 10 Oktober 2019: 2110-2125; PENDAYAGUNAAN MODAL SOSIAL PERSPEKTIF EKONOMI ISLAM PADA (STUDI KASUS KOPERASI SYARIAH DI PONDOK PESANTREN UMMUL QUROO SURABAYA)

Putnam (1993) dalam Lawang (2004:

67) menyatakan bahwa keanggotaan seseorang dalam suatu institusi memberikan peluang dalam mengatasi berbagai permasalahan. Lawang (2004: 68) mengungkapkan hipotesis jaringan mengenai keagamaan, bahwa semakin tinggi aktivitas keagamaan maka akan semakin memudahkan pembentukan jaringan, dan jaringan keagamaan lebih tinggi terjadi pada orang-orang yang aktif daripada yang pasif. Berdasarkan hipotesis tersebut maka Pondok sebagai salah satu institusi keagamaan memiliki peran penting dalam pembentukan jaringan antar individu dan institusi. Kegiatan Pondok yang bervariasi akan menumbuhkan sikap aktif pada santri maupun jama'ah yang mana akan memudahkan dalam pembentukan jaringan.

Pondok Pesantren memiliki kegiatan yang banyak dan bervariasi yang sengaja dibuat agar menjadi daya tarik bagi jama'ah dan santri. Dalam membuat program kerja, Pondok Pesantren melihat apa yang menjadi kebutuhan jama'ah dan santri. Pondok Pesantren Ummul Quroo tidak hanya sebagai tempat kajian untuk jama'ah dan masyarakat sekitar, namun juga menyediakan berbagai kebutuhan jama'ah dan tidak membebani masyarakat. Hal ini kemudian akan menumbuhkan ikatan dalam diri jama'ah terhadap Pondok sebagai suatu institusi keagamaan yang mampu memberi solusi atas persoalan yang dihadapi para jama'ah.
Pondok Pesantren Ummul Quroo memberikan kontribusi dalam memecahkan berbagai persoalan jamaah mengenai bidang kesehatan, sosial, dan juga ekonomi. Dalam bidang kesehatan, Pondok Pesantren Ummul Quroo memberikan layanan Poliklinik dan Cek kesehatan yang tersedia gratis bagi jamaah. Dalam bidang sosial, Pondok Pesantren Ummul Quroo mengadakan pendataan kondisi jamaah bagi yang kurang mampu serta memberi bantuan kitab Al-Qur'an dan hadits secara gratis. Dalam bidang ekonomi, Pondok Pesantren Ummul Quroo berperan dalam membebaskan masyarakat dari rentenir, memberikan sedekah beras, dan dengan adanya Kopontren Ummul Quroo dapat memberi bantuan modal usaha, promosi usaha, serta memberi manfaat kepada jama'ah.

Jaringan akan menjadi semakin baik apabila masing-masing pihak turut memberikan kontribusi. Apabila Pondok Pesantren Ummul Quroo telah menyediakan berbagai macam layanan, maka individuindividu dalam masyarakat dapat memberikan peran aktif dalam berbagai kegiatan Pondok Pesantren tersebut. Pondok Pesantren Ummul Quroo juga membentuk pemuda dan pemudi Ummul Quroo yaitu sebuah gerakan kepemudaan yang juga mengatur dan melihat situasi kondisi para jama'ah, dimana dengan mengelola infaq yang diberikan jama'ah akan kembali untuk jama'ah dalam rangka mensejahterakan dan juga memberdayakan para jama'ah yang 
Dinullah, et al/Jurnal Ekonomi Syariah Teori dan Terapan Vol. 6 No. 10 Oktober 2019: 2110-2125; PENDAYAGUNAAN MODAL SOSIAL PERSPEKTIF EKONOMI ISLAM PADA (STUDI KASUS KOPERASI SYARIAH DI PONDOK PESANTREN UMMUL QUROO SURABAYA)

punya keahlian didalam bidang apapun agar bisa saling memberikan manfaat baik bagi individu dengan institusi (Pondok). Gerakan ini dapat meningkatkan partisipasi jama'ah dalam berinfaq dan yang tidak, sehingga jumlah infaq yang terkumpul semakin bertambah dan semakin bertambahnya infaq maka semakin meningkat kuantitas dan kualitas layanan Pondok Pesantren Ummul Quroo.

\section{Proses Pembentukan Jaringan Antar Institusi}

Proses pembentukan Jaringan antar institusi memiliki bentuk yang lebih kompleks dibanding jaringan antar individu atau antar individu dan institusi. Hal ini dikarenakan dalam satu jaringan berkumpul jama'ah dan kelompok dengan latar belakang berbeda, kemudian bertemu dan berinteraksi dengan institusi lain yang terdiri dari berbagai anggota dengan latar belakang yang berbeda pula. Masingmasing anggota mewakili institusinya, bertindak dan berpendapat atas nama institusinya. Menurut Lawang (2004: 68) adalah Jaringan antar institusi ini biasanya bertujuan untuk memecahkan masalahmasalah umum yang dihadapi bersama, berdiskusi, dan bertukar pikiran untuk mencari solusi.

Pondok Pesantren Ummul Quroo memiliki jaringan yang baik dengan Pondok lain maupun institusi lain diluar institusi keagamaan. Sebagai salah satu rujukan dan bahan diskusi tentang pemberdayaan ekonomi jama'ah, Pondok Pesantren Ummul Quroo adalah salah satu pondok yang sering mendapat kunjungan dari Pondok lain yang notabene berada di luar wilayah Surabaya. Pondok Pesantren Ummul Quroo memiliki daftar tamu kunjungan studi banding untuk memudahkan pendataan. Ada pula hubungan yang terjalin antara Pondok dengan sponsor-sponsor. Ketika mengadakan acara, banyak sekali sponsor yang berkontribusi dalam meramaikan kegiatan di Pondok Pesantren Ummul Quroo, memberikan sumbangan maupun bentuk kerjasama lain. Berkenan dengan hal ini, Pondok Pesantren Ummul Quroo telah dapat membangun kepercayaan dihadapan institusi lain sehingga terjalin kerjasama antar institusi.

Jaringan yang terbentuk antar Pondok dan institusi lain tersebut dilakukan tidak lain adalah untuk mengatasi masalah secara efektif dan efisien. Suatu problematika ummat akan lebih mudah diselesaikan jika dipikirkan bersama. Dengan terhubungnya satu institusi dengan institusi lain, maka informasi akan semakin bertambah, produktivitas meningkat, serta terjalinnya kerjasama yang saling menguntungkan. Hal inilah yang nantinya akan mendorong pengembangan modal sosial dalam masyarakat.

\section{v. SIMPULAN}

Berdasarkan hasil dan pembahasan penelitian tersebut, dapat ditarik beberapa kesimpulan, yaitu:

1. Pondok Pesantren Ummul Quroo memiliki peran dalam mengembangkan modal sosial masyarakat sekitar melalui berbagai program kerja Kopsyar Ummul Quroo serta pengelolaan atau 
Dinullah, et al/Jurnal Ekonomi Syariah Teori dan Terapan Vol. 6 No. 10 Oktober 2019: 21 10-2125; PENDAYAGUNAAN MODAL SOSIAL PERSPEKTIF EKONOMI ISLAM PADA (STUDI KASUS KOPERASI SYARIAH DI PONDOK PESANTREN UMMUL QUROO SURABAYA)

manajemen Pondok yang ditetapkan yang sesuai dengan kebutuhan jama'ah dan masyarakat sekitar.

2. Bentuk pemberdayaan ekonomi jama'ah yang dilakukan oleh Koperasi Pondok Pesantren Ummul Quroo dengan menjadikan Kopontren UQ sebagai lapangan pekerjaan juga tambahan pendapatan dan dapat dikatakan Kopontren UQ berperan namun belum secara maksimal.

3. Kedepannya, Kopontren UQ akan menjadikan koperasi yang sebelumnya koperasi serba usaha menjadi koperasi simpan pinjam. Mengingat Kopontren ini telah memiliki peran pemberdayaan ekonomi jama'ah pesantren yang kurang maksimal dan berusaha memaksimalkan dengan diperbaruinya bentuk Kopontren ini menjadi bentuk simpan pinjam atau bentuk lainnya yang diharapkan lebih memiliki peran yang tinggi untuk jama'ah pesantren.

\section{DAFTAR PUSTAKA}

Akmal dan Zainal Abidin. 2015. Korelasi Antara Islam dan Ekonomi. Jurnal Penelitian, Vol. 9, No. 1 (2): 1-18.

Bungin, M Burhan. 2007. Metodologi Penelitian Kualitatif. Jakarta:Kencana Chaniago, Arifinal. 2001. Ekonomi dan Koperasi. Bandung : CV Rosda Bandung.

Fitrianto, Achmad Room. 2005. Peran Pesantren dalam Pengembangan Perekonomian Rakyat. Makalah disajikan dalam diskusi panel Penguatan Ekonomi Pesantren dan
Tantangan Perubahan oleh Center for Islam and Democracy Studies, Bangkalan, 26 September 2005.

Fukuyama, Francis. 1999. The Great

Disruption: Hakikat Manusia dan Rekonstitusi Tatanan Sosial. Yogyakarta: Penerbit Qalam. Penerjemah: Ruslani.

Hasbullah, Jousairi. 2006. Social Capital: Menuju Keunggulan Budaya Manusia. Indonesia. Jakarta: MRUnited Press.

Kudhori, Moh. Amin. 2013. Pemberdayaan Ekonomi Umat Islam Dalam Prespektif Al-Quran. Skripsi tidak diterbitkan. Semarang: Fakultas Ushuluddin Institut Agama Islam Negeri Walisongo.

Lawang, Robert M. Z. 2004. Kapital Sosial Dalam Perspektif Sosiologik: Suatu Pengantar, Depok: FISIP UI PRESS Mohammad Hatta. 1954. Beberapa fasal Ekonomi jilid 1 Dijalan Ke Ekonomi dan Koperasi. Jakarta: Perpustakaan Perguruan Kementrian.

Muslim, Azis. 2014. Model Pemberdayaan Ekonomi Masyarakat Miskin Perkotaan Berbasis Tanggung Jawab Sosial Masjid. Disertasi tidak diterbitkan. Surakarta: Pascasarjana Penyuluhan Pembangunan Universitas Negeri Surakarta.

Nadzir,M.2015. Membangun Pemberdayaan Ekonomi Pesantren. Economica, 6(1), 37-56

Prijono, Onny S. dan A. M. W. Pranarka (Eds.). 1996. Pemberdayaan: Konsep, 
Dinullah, et al/Jurnal Ekonomi Syariah Teori dan Terapan Vol. 6 No. 10 Oktober 2019: 21 10-2125;

PENDAYAGUNAAN MODAL SOSIAL PERSPEKTIF EKONOMI ISLAM PADA (STUDI KASUS KOPERASI SYARIAH

DI PONDOK PESANTREN UMMUL QUROO SURABAYA)

Kebijakan dan Implementasi.

Jakarta: Centre for Strategic and

International Studies.

Quthb, Sayyid. 2004. Tafsir Fi Zhihalil-Qur'an.

Terjemah oleh As'ad Yasin dan Abdul

Aziz Salim Basyarahil. Jilid 1-12.

Jakarta: Gema Insani Press.

Sanrego, Yulizar D. dan Taufik. 2016. Fiqih

Tamkin (Fiqih Pemberdayaan).

Jakarta: Qisthi Press.

Sugiyono. 2010. Metode Penelitian

Kuantitatif, Kualitatif, dan R\&D.

Bandung: Penerbit Alfabeta.

Wahyuningsih. 2016. Pengaruh Input Produksi

Wakaf Berupa Modal dan Tenaga

Kerja Terhadap Produktivitas Aset

Wakaf Pada Lembaga Wakaf

Produktif Yayasan Badan Wakaf

Sultan Agung Semarang. Surabaya:

Universitas Airlangga. Skripsi Tidak

Dipublikasikan.

Wibowo, T. W. 2014. Rasionalitas Member

Dalam Melakukan Bisnis Trading

Forex Di Kota Malang (Studi Kasus

terhadap Member Grup "Amanah" di

Kota Malang). Malang: Universitas

Brawijaya.

Yin, Robert K.1996. Studi Kasus: Desain dan Metode. Jakarta: PT Raja Grafindo

Persada. Penerjemah: Djauzi

Mudzakir. 